Tér és Társadalom 18. évf. 2004/3. 151-154. p.

Tér és Társadalom

XVIII. évf. 2004

3: $151-162$

\title{
KÖNYVJELZÖ
}

\section{POMPEI COCEAN: GEOGRAFIE REGIONALĂ}

\author{
(Presa Universitară Clujeană, Cluj Napoca, 2002. 157 o.)
}

\section{NEMES NAGY JÓZSEF}

A kelet-közép-európai regionális, földrajzi kutatásnak csupán a sajátos helyi ügyekre szúkülő provincializmusa és gyermekes csüngése a nyugat-európai és amerikai tudomány valós eredményein és az azoknál jóval tágabb teret lefedỏ publikációdömpingjén (lásd Tímár Judit néhány újabb kritikai fơldrajzi indíttatású írását) egyenesen hozza magával a történelmileg sok tekintetben hasonló utat járó, aktuálisan hasonló problémákkal küszködő országok kutatói egymásra figyelésének teljes hiányát. Különösen igaz ez a nem, „világnyelven” (angol) született mủvekre. Ezek szinte kivétel nélkül tágabb visszhang nélkül maradnak. Ezt, a megítélésem szerint elfogadhatatlan helyzetet szeretném oldani kissé a kolozsvári Babes-Bolyai Egyetem Földrajzi Kar dékánja számos érdekes - a magyarországi tudományos mezőben is értelmezhető - következtetésre lehetőséget adó munkájához füzött rövid reflexióimmal.

A közepébe vágva: már maga a mú címe (Regionális földrajz) - általában is, de az érintett diszciplína körüli (lanyha) hazai viták tükrében különösen - azonnal érdeklödést kelt. Vajon milyen tartalmat rendel a diszciplínához, milyen szemléletet képvisel e cím mögött egy román kutató? A válasz elég világosan megadható. Cocean regionális földrajza lényegében semmi kötődést nem tartalmaz a regionális fỏldrajz hagyományos leíró, klasszikus vonalához, s ebben a tekintetben aligha használható például egy egyetemi regionális földrajzi kurzusblokk bevezetőjeként, sokkal inkább egy általános társadalom-földrajzi alapvetésnek tekinthetỏ. Középpontjában nem a régió fogalma áll (bár ezt a kategóriát is tárgyalja), hanem a tér, a térbeliség, a térszerkezet, a különbözó térségtípusok (határozott geográfiai hangsúlyokkal).

Ebbỏl is következően, a mü sok tekintetben - talán a szerző alapvetỏ célkitủzésével szemben is, meg merem kockáztatni a véleményt - sokkal inkább a magam szemlélete szerint regionális tudományhoz közeli, mintsem a regionális földrajz általánosan bevett tartalmához. Ennek konkrét momentumai például, hogy egyes fejezeteiben markánsan megjelennek az alapvető térkategóriák, a különböző térszemléletek, a térelemek s azok kapcsolódásai, modelljei. Mindezzel a mú nagyon erőteljesen érvel a regionális földrajz tértudományi jellege mellett. (A térelméleti fejezetekben - szemben a hasonló magyar munkákkal - nagy hangsúllyal van jelen a francia társadalomföldrajz és társadalmi térelmélet elméleti és modellezỏ szemlélete, ami színvonalában is méltó partnere a nálunk preferált német és angolamerikai iskoláknak.) 
Tapasztalataim szerint ma Romániában nemcsak a regionális fejlesztés gyakorlatias kérdésköre van elötérben, hanem érzékelhető az elmozdulás a regionális tudományi szemlélet irányába is (ha nem is használják ezt a diszciplináris meghatározást, intézményi és történeti okokból talán érthetöen). Cocean kötetében mindez a regionalizáció sokoldalú tárgyalásában jelenik meg (a romániai történeti-mentális régiók, a természeti tájak és a politikai-adminisztratív térfelosztás egymásmelletiségének és ütközésének világos érzékeltetésével). Ennek az elmozdulásnak égető aktualitást ad az ország EU-csatlakozásának reális távlata is. Ahogy a magyar tapasztalat is mutatja, az Unió eröteljes regionális politikai eszközrendszerének befogadásához, a remélt források elnyerésének nélkülözhetetlen (ha mindezek gyakorlatias jellege okán nem is elsődleges) eleme a kapcsolódó, határozottan gazdasági és társadalmi töltetü regionális kutatási háttér is. Ami a kötetben a magyar helyzethez képest viszonylagos fáziskésést jelez, az a közgazdasági makrokategóriák (jövedelem, töke, munkanélküliség stb.) menti térszervezödés érdemi bemutatásának, s mindennek egyenes következményeként a helyénvaló kvantitatív módszertani elemzési kultúra eredményeinek érzékelhető hiánya. Megítélésem szerint e két momentum még akkor is nagyobb hangsúlyt érdemel, ha megmaradunk a regionális földrajz megnevezésnél.

A geográfikum egyrészt olymódon bukkan felszínre a müben, hogy az általános térfogalmak, modellek a földrajztudomány jól ismert nemzetközi (alapvetően európai) történeti áramlataiból, jeles klasszikusainak szemléletéből és modelljeiböl építkeznek. Ugyancsak a geográfiai karaktert erősíti a természetföldrajzi fogalomkészlet, a természeti és társadalmi térszerveződés kölcsönkapcsolatának erőteljes hangsúlyozása. E két vonalon teljes egyezésre aligha tudnék rámutatni, a rokonság mindenesetre erőteljesebb Probáld Ferenc vagy Mészáros Rezső hazai mun káihoz, mint a magam írásaihoz, bár a két hazai kiválóság esetében jóval visszafogottabb a természetföldrajzi kontaktus, s markáns a társadalom-földrajzi tartalom. A természeti és társadalomföldrajz szoros összekapcsolása elterjedt (de távolról sem egyedüli) kutatói álláspont világszerte, nehezen küzd azonban egy gyakorlatias ellentmondással: az egységes földrajz fenntartható, de csak ténylegesen komplex, kiegyensúlyozott természeti és társadalmi elemekböl épülő tudományos kutatások bázisán, ha pusztán elméletben, modellek, sémák szintjén tartják (tartjuk) fenn az egységet, az nem lehet életképes. Az egységes földrajz piacképessége elméletileg nagy, gyakorlatban azonban rendkívüli erőfeszítéseket, hatalmas munkát igényel az, hogy ez valóságos komplex földrajzi tudományos eredmények formájában öltsön testet. Ez felvállalható, de csak a feladat, a munka nagyságának tudatában. Bár a kötet ilyesmit sugall, a regionális földrajzot magam nem tartom valóságos „harmadik útnak", a vágyott szintézis terepének, abban is határozott a természeti és társadalmi kettösség. Nemcsak az egységes földrajz melletti érvek sorolhatók, hanem a társadalomföldrajz lehetséges alternatívája is megfogalmazható: nyitás a kapcsolódó társadalomtudományok, a közgazdaságtan, a szociológia, a tervezéselmélet, a politológia felé, annak reális esélyével, hogy a társadalomföldrajz ezektöl nem pusztán „,kaphat” valamit (új eszközöket és szemléletet), hanem maga is ,adhat”: 
mindenekelött a társadalmi térbeliség megjelenítésének eszközeit e területeken. Ugyanakkor mindez nem jelenthet éles szakítást: a természeti és társadalmi földrajz egymás közötti kapcsolatai minden további nélkül fenntarthatók és fenntartandók egy másfajta külső tudományos és szervezeti kapcsolatrendszer mellett is. E kérdéskörök mögött Romániában az, a magyarországinál jóval nyilvánvalóbb helyzet is megbújik, hogy a természeti és társadalmi földrajz viszonyrendszerében - a sajátos, részben direkt politikai faktorok által determinált tudományos fejlödésmenet következtében - ma még jóval határozottabb a természeti földrajz dominanciája, ami az aktuális társadalmi trendek tükrében megítélésem szerint mindenképp arányosítást kíván.

A kötet fontosságát (más hasonló karakterủ, részben - például Benedek József tollából - magyar nyelven megjelent erdélyi kötetek mellett) a maga tudományos tartalmán túl az is növeli, hogy egyetemi mühelyben, a legfontosabb „célcsoport”, a jövő geográfus generációja közelében készültt. Egy bizonyos életkor (kb. 50 év) felett a társadalomkutatók egy csoportjának - magamat is közéjük sorolom - szinte törvényszerủ pályája az „elmélet” felé fordulás. A felhalmozódott tapasztalatok, tudás összegzésének igénye kapcsolódik itt össze realista módon az időhiánnyal, az adminisztratív feladatok nyomásával (az elméleti összegzések papírra vetése kissé egyszerübb és kevésbé munkaigényes, mint hatalmas empirikus adatgyüjtések hoszszadalmas feldolgozása). Cocean kötete is e sorba kapcsolódik, bízom benne, hogy fiatal román és magyar olvasói is érdeklódéssel olvassák (nem pusztán megtanulni kell a benne leírtakat, hanem tovább gondolni).

A kötet a hazai regionalisták számára azt az üzenetet hordozza, hogy a „közös nyelv" nemcsak a szavakban és a grammatikában keresendő (a román szakszöveg a francia nyelv alapelemei ismeretében egyébként kis erőfeszítéssel megérthetỏ), hanem az aktuális társadalmi kérdésekre adott tudományos válaszokban, amelyek nemcsak a távoli „fejlett” régiók folyóirataiban találhatók meg, hanem a szomszédban is. Ahogy reflexióim jelzik, a kötet több momentumával magam vitában vagyok, de talán épp ezért is ajánlom a hazai kutatói közösség figyelmébe is e munkát, amelyet az önálló közép-kelet-európai regionális kutatási erőfeszítések példaértékü dokumentumának tartok. 
Tér és Társadalom 18. évf. 2004/3. 151-162. p.

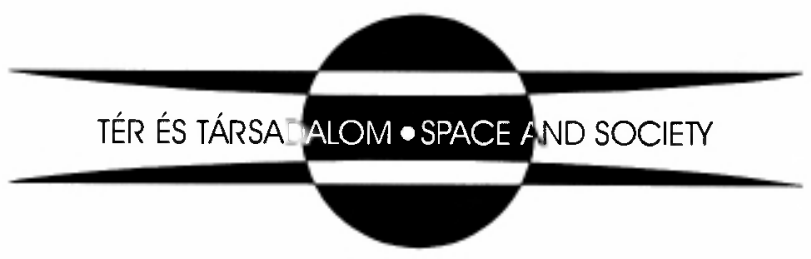

